\title{
Africa Debt Crisis and the IMF
}

\section{with a Case of Nigeria:}

\section{towards Theoretical Explanations}

\author{
Brian-Vincent IKEJIAKU \\ Research Institute of Law, Politics and Justice \\ Keele University, Keele, Staffordshire, ST5 5BG, UK \\ Tel: 44-79-4476-5923 \\ E-mail: b.v.o.ikejiaku@ilpj.keele.ac.uk OR ike.bvo06@yahoo.com
}

\begin{abstract}
This paper, attempts to employ and apply the dependency and liberal economic theories in order to demonstrate how these two theories help in the accurate analysis and explanations of the debt crisis in the developing countries, particularly Africa and especially Nigeria. In doing this, the paper considers very briefly some of the actions and policies of IMF and other IFIs, the administrations of some Nigeria leaders and the undertakings/trend of events during the implementations of the Structural Adjustment Programme in Nigeria. It also reflects some of the activities in other countries in Africa relevant to the analysis. The paper concludes that the IMF, World Bank and the West should be blamed for collaborating with some Nigeria leaders in making the country indebted. And that the Nigerian masses needed reparation for the losses, pains and sufferings they have passed through because of IMF's SAP.
\end{abstract}

Keywords: IMF, SAP, Dependency, Liberalism, Debt, Corruption, Africa, Development

\section{Introduction}

An accurate account and proper analysis of the debt crisis in developing countries of Africa, and Nigeria in particular cannot be possible without the examinations of some theories underpinning the problem. Scholars and writers have emerged with different theories and explanations concerning the debt crisis in developing poor countries. The protracted debt crisis in these countries has stimulated research projects that endeavour to unravel the causes, and explain the complexities surrounding the debt crisis. While some studies argue that dependency theory (Baran, 1957, Frank, 1971) is best for understanding the debt crisis, others maintain that development theory (Rostow, 1960) or economic explanations (Offiong, 1980) is more lucid. Yet, others contend that political explanations (Migdal, 1988) or the liberal theory (Burchill, 1996) is important. For the purpose of this paper, the dependency and liberal economic theories will be considered.

\section{Dependency Theory and Liberal Economic Theory}

\subsection{Dependency theory and Africa's debt crisis}

Proponents of the dependency theory contend that the debt crisis in Africa could be perceived from the extreme dependence of Africa's economies on international competitive economic conditions over which they had little control. Dependency theory is predicated on the notion that there is a 'centre' of wealthy states and a 'periphery' of poor, underdeveloped states. Resources are extracted from the periphery (developing nations) and flow towards the states at the centre (developed nations) in order to sustain their economic growth and wealth. The major contention here is that the economic development of the developing countries (the Global South) was rendered impossible by the domination of the global economy by the already industrialized capitalist powers ('the Global North', Offiong, 1980). The implication is that poverty; including indebtedness of the countries is the result of the manner of their integration of the world system. The historical incorporation of dependent territories into global division of labour entailed a tendency toward economic stagnation in the colonies and neo colonies (Sandbrook, 1982).

Therefore, scholars for example, agree that American based multinationals own overseas investments too large to have been generated by the capital transferred by these companies out of U.S. Their net returns of foreign exchange to the U.S. are also reported to be very high and growing. The net effect is that holes are continuously knocked into the pockets of these poor countries and the degree of their impoverishment is growing more and more until they acquire the 
psychological impression that the only way they can support investment is through foreign loans - loans which once acquired are swept away by worsening balance of trade (Baran, 1954; Frank,, 1971; Rodney, 1974 and Sweezy, 1978). These developing countries go for more loans hoping that this will help improve the situation, but the conditions tied to these loans always spell trouble and doom for these less developed countries (LDCs); as in the words of George Washington, the former president of U.S. 'it is madness for one nation to expect disinterested help from another - the U.S. does not have friends, but interest' (in Abbah, 1996). Thus dependency tightens its grip; as the LDCs go for more loans from the financial institutions and donor countries. This is the phenomenon which Cheryl (1974) called 'debt trap'. At this point, dependency becomes inescapable.

\subsection{Liberal economic theory and Africa's debt crisis}

The liberal economic theory also offers plausible contention on the debt crisis in developing countries. The major argument here is that economic liberalization will help in the increase of flow of foreign investment into the developing countries, as a result of the easing of trade and exchange restrictions. The notion is that in the process of homogenizing the political economy of every member state of the international community that the objective of creating a market society on a global scale is within reach (Biersteker, 1993). Again, one of the major objectives of liberalization is to reduce the resource gap in the LDCs, by improving the trade balance and encouraging a net capital inflow. Thus, the growing importance of international organizations such as the G7, IMF and World Bank is indicative of the influence of liberal economic internationalism in the post-Cold War period (ibid).

However, events in the developing world provide us with some reasons why attempts made in redressing the situation through the encouragement of increased foreign borrowing have contributed to the current debt crisis by increasing the resource gap even further. These powerful transnational bodies which embody free trade liberalism as their governing ideology however impose free market strictures on developing societies. Since they are the primary organizations which formalise and institutionalise market relationships between states; they lock peripheral states into agreements which force them to lower their protective barriers (GATT and NAFTA for instance), thereby preventing developing nations from developing trade profiles which diverge from the model dictated by their supposed 'comparative advantage' (Burchill et al, 1996). The IMF and the World Bank for example, make the provision of finance (or more accurately 'debt') to developing societies conditional on their unilateral acceptance of free market rules for their economies, the conditionality of the so called - structural adjustment programme 'SAP' (ibid).

The IMF's preconditions, which have their theoretical roots underpinning in monetarist doctrines, show no sensitivity or consideration to the peculiar underdeveloped nature of the economies, and as a result, the prescriptions have had the effect of threatening their very survival (Onimode, 1989). In fact one such conditional ties has been the insistence that the currencies of these countries be devalued. The application of this condition for example in Zambia 1985, Ghana and Nigeria in 1986, suggests that these economies are far from improving, rather it has worsened them, and thereby raises fundamental questions to their long term usefulness (ibid).

Besides, there is a large element of uncertainty in the minds of the donor bodies regarding the ability and stamina of the state in Africa, for example to stem the tide of opposition to overall adjustment policies, and thus meeting the expectations of loan repayments. The Zambian and Nigerian experience are cases in point (ibid). And by implication how long the programmes can be continued considering the serious hardship imposed on the people. Therefore, the lending organisations advance a lackluster approach to African countries. Above all, there is further submission that these financial institutions created an easy or sophisticated means through which corrupt leaders in developing countries can use to stash their nations' wealth into tax havens; therefore, worsening the debt crisis, and deepening the level of absolute poverty to what Ikejiaku (2008, 2009 'in press') coins the term poverty qua poverty to explain. The developed world contribute in Africa's capital flight, 'The poor countries are constantly de-capitalised and their economies remain largely upon decision made in New York, London, Paris and other metropolitan centres' (Holsti, 1995). For example, Zarian Mobutu, Abacha and Babangida in Nigeria must have embezzled more than \$5billion each and Kenyan Arap Moi \$1billion (Azami, 2005).

All these were part of the factors that rendered the African economy weak, and therefore necessitated or led to their financial plight, dependency relation and subsequent interests and demand for foreign loans. Yet, the manipulations by the financial institutions and other lending agents, which were made feasible by the introduction of liberalism in Africa, helped in impacting negatively to the purse or coffers of African states, thus aggravated the debt crisis in the continent. For example SAP failed the majority of Nigeria; particularly it brought mass unemployment (AFRODAD, 2007). Kenya also continues to express its displeasure at the IMF and the World Bank for forcing these policy changes on it (Wayande, 1997). In the early 1980s, Uganda was rocked by weeks of demonstrations, as industrial workers and students took to the streets to denounce President Miton Obote's IMF-imposed economic programme and in 1990, Matthew Kerokou of the Benin Republic in West Africa was removed from power following a wave of anti-SAP riots (Dare, 2001). It is therefore not surprising and understandable while notable scholars, such as Sachs (2005: 189) lambastes the IMF and World Bank for imposing draconian budgets to support SAP, which had: 'little scientific merit 
and produced even fewer results' It could rightly be argued that it is no coincidence that government that continued to operate quite well (e.g. Botswana) never had to subject themselves to the painful cure of SAP (Hyden, 2000).

In summation, therefore, this paper will apply the two theories (dependency and liberal internationalism) discussed above in the analysis of the Africa debt crisis and the IMF's structural adjustment programme, with particular emphases on Nigeria.

\section{Africa, Nigeria and Debt Crisis}

\subsection{Background to Nigeria's Debt Crisis}

The Nigeria state, just like many other states in Africa (example, Kenya, Democratic Republic of Congo, formerly Zaire and Ghana to mention but a few) in the 1960s and early 70s were not indebted. When Nigeria obtained independence in 1960, the world believed that, she will usher in economic prosperity for her citizens. It was because of this thinking the world saw Nigeria as the future economic giant of Africa (AFRODAD, 2007). The thinking was not a mere wishful idea because: Oil, the money-spinner, had been discovered at Oloibiri in present-day Bayelsa state in 1956. By 1958, Nigeria had begun to export the black gold to earn petrol-dollars. Also, agriculture was booming; cash and food crops were being produced massively and were fetching for the nation much foreign exchange. In fact, suffice it to say that Nigeria was blessed with an abundant and a viable human resource base, a favourable climate and a vast expanse land more than twice the size of Britain (ibid).

Actually, Nigeria, comparatively with other developing countries, was rich. She had no reason to go a borrowing. In fact, Nigeria later successfully financed her 30-month civil war from 1967 to January 1970 without taking a foreign loan. It was this that made General Yakubu Gowan (1966-1975), Nigeria's military head of state, at the time, once vaulted during the early 1970s that Nigeria problem was not cash, but rather what to use the available money to do.

However, trend of events during some of the successive governments and administration from the periods of General Obasanjo's regime (1976-1979) till Babangida and Abacha regimes (1985-1998), surprisingly, cause the nation's 'boast' to begin to fade. She then discovered that to keep moving, she had to take foreign loans. In no time, she was subsequently caught up in a crippling foreign debt crisis that besides compromising its economic progress, political stability, social dignity and cultural integrity, also dealt a debilitating blow to the Nigerian masses, because of the pains and sufferings they passed through during SAP.

\subsection{Application of Dependency and Liberal Theories}

Dependency theory and the liberal economic theory provide us with the most informed explanations on why Nigeria degenerated to the statue of indebted nation. In the late 1970 and 1980s, disillusion with statist approaches and the ascendancy or dominance of neo-conservative governments in Britain, the United States, and to some extent in West Germany - provoked a shift toward a liberal market oriented paradigm. Specifically, failings in the form of mistaken polices (particularly in United States under President Regan and Britain under Thatcher), not essentially the workings of the global economy or globalisation were identified as the prime cause of economic stagnation in the Third World (Okafor, 2004). The current global development philosophical approach, particularly by the developed capitalist nations and international financial institutions is still critical on machinists of developing countries' economies, as the cause of their economic development backwardness:

Today's revised development ideology retains both the emphasis upon domestic sources of economic malaise, and the faith in liberal economic policies. What is new is the belated recognition of the centrality of the state, and in particular, accountable government, to sustained capitalist development (Sandbrook, 1993: 2).

The above fact could be better understood from the perspective of the World Bank's Seminal report of November 1999 titled: Sub-Saharan Africa: from crisis to sustainable Growth which was an exceptional clear and authoritative account of the call for liberal economic and free enterprise model for Africa's recovery. And as a way of providing the much needed solution to economic problem of Africa, particularly the debt crisis, the IMF and its cohort (the World Bank) which arrogated to themselves, the right and responsibility of putting Africa in the right part, agree inter-alia, that Africa needs not just government but better government that concentrates its efforts less on direct interventions and more on free trade liberalism. The Bank's report claimed that what characterized most African countries was a bloated capricious-management and faulty policy. Hence:

The Leviathan must be tamed, redirected, and made effective? The Bank proposed in effect, to convert the monopolistic African states into liberal democracies linked to enlarge and rejuvenated private sectors, and to build the reformed states' institutional capacity (Amin, 1994: 45).

However, a superficial reflection on the expatiated report of the IMF (and the World Bank) would show the plan as appealing option for the continent, but a critical study into the factors that led to the role of these two institutions were/are playing in the economic development of Africa would show that, after all, IMF and World Bank could be 
nothing but instruments of neo-colonialism. The activities of these financial institutions were more or less to maintain the dependency nature of African countries (Okafor, 2004).

This submission becomes glaring and more convincing when it is appreciated that the IMF was initially a pure European establishment. During the first period of its existence, the IMF gave the impression of certain efficiency as it helped to re-establish the convertibility of European Currencies (1948-1957); then helped European economies adjust (1958-1966). From 1967 on however, the fund failed to maintain stability despite the creation of Special Drawing Rights (SDRS). (Parity adjustments were numerous after this date: devaluation of the Pound and the Franc, revaluation of the Mark and the Yen, floating of the price of gold etc).

The adoption of the General system of floating currencies in 1973 may be considered to mark the end of the Breton Wood's mandate. At a point, the continued existence of the IMF was called into question. The institution survived by taking new functions: Management of unilateral structural adjustment in developing countries, and, from the end of the 1980s, intervention in Eastern countries with the goal of ensuring the re-incorporation of these countries into the international monetary system (Amin, op cit: 36).

Imperatively, and drawing from the above revelations, one might be tempted to ask why an institution (IMF) which once failed to deliver in Europe was drafted to take the lead in the economic recovery of Africa and other developing world? Surprisingly, and as if oblivious of the question of incompetence on the part of the IMF, the Western governments moved to implement the recommendations of the institution by granting of loans/aids to any African state that follows the IMF's economic liberalization policies. In Africa, this was midwifed through SAP.

Development Forum informs us that the annual expenditure on health in the poorest countries average less than $\$ 5$ per person. In wealthier countries such as USA, Canada etc. health expenditure average $\$ 400$ per person (Onimode, op cit). This is because the poor are either entirely unemployed or underemployed. The situation is contrary to the decades before SAP reforms were introduced, and as the 1997 IMF Report has confirmed. According to it, in the decade prior to 1985, many countries experienced annual growth rates of employment in excess of 5 percent (including Ghana, Mali Mauritania, Niger, Tanzania and Togo) with some as high as 10 percent per annum (ibid).

Again, the loans and aid administration from the developed to underdeveloped African states remain economically retrospective. On this pedestal, it can be pointedly contended that, one of the biggest stumbling blocks to Africa's social development in modern times was the external debt crisis. Not only did the West, through the instrumentality of IMF deplete financial resources and channel capital flows from poor countries to rich countries through interest payments, it retarded economic development and increased poverty (Filomena, 1997).

As it is with loans, so it is with aids to Africa. The liberal economic policies, coupled with the integration of the continent into the international economic system, have been argued to have both the implications of indebtedness and poverty perpetuating (Onimode, op cit). At times, the aids are either insufficient or go with unfriendly conditionality. At other time, it is diabolically handled to be ineffective. For example in 1994, the whole of Sub-Saharan Africa received fund for Development and Industry (FDI) flows worth $\$ 1.8 \mathrm{bn}$, the size of flows to New Zealand. The whole of North Africa received \$1.3bn, the size of foreign investment in only Portugal. The Total official Development Assistance (ODA) to Sub-Saharan Africa in 1970-1996 was only \$39.157bn (Sharitayanam et al, 2001), and in 1999-2000, ODA for basic social services averaged $\$ 4.9 \mathrm{bn}$ (World Bank, 2000). The IMF and World Bank note with sadness, that in some cases, aid is tied to purchases of goods and services approved by the donor country. Such restrictions reduce the effectiveness of aid and undermine the principle of country ownership (ibid). That is not all, the most pathetic of it all is that most of the so-called aids given end up not leaving the donor country. To say the least, this is exploitation, this is also imperialism, this is a means to maintain the dependency relationship with African continent, and this is as well the ill fate accompanying liberalism in Africa. Just as Irungu (1994) captures:

For every dollar allocated for US aid, up to 70 percents will never leave the US. Each year, roughly $\$ 70 \mathrm{bn}$ will be spent on purchasing goods and services in cities such as New York and Texas. Up to 80 percents of all British goods and contracting British services... For every dollar that entered the continent in loans, grants (and) investment three dollars left as profits, debt servicing and interest.

\subsection{Nigeria Leaders, Debt Crisis and IMF}

It is rather unfortunate, that African leaders know this too well but still accept the loans and aids even in the face of their incapacity to pay back. This is why some less corrupt and more reliable regimes such as the government of Shagari and Buhari did not succeed in getting the IMF loan. This is because these leaders were very convinced that their administrations cannot comply with all the conditionality or prescriptions that follow SAP. Again, these leaders considered the plights and sufferings, which the Nigerian masses will pass through if they accept complying with IMF's prescriptions. For example, the government of Shagari is noted to have assessed the IMF financial facilities after approaching the institution on loan assessment sometimes in 1983. Nigeria, under Shagari's regime sought to borrow $\$ 2$ billion from the fund, largely to help refinance, and had initiated negotiation with IMF. However its trade debt then 
estimated to be between $\$ 3$ billion and $\$ 5$ billion has not been serviced, and Nigeria was unwilling to comply with IMF guidelines; therefore, his administration did not succeed in getting the IMF loan (Biersteker, 1993). And by the period Shagari left office in 1983, Nigeria was indebted to \$14,130.7 million (CBN Annual Report, 1988).

Also, under Buhari government; in spite of the fact that the Buhari administration serviced her foreign debts more than other regimes, the IMF, acting through the US blocked the loan application of $\$ 1.6$ billion which the government of made to Saudi Arabia in February 1984. This yet compelled Buhari's government to start negotiations with IMF in late February 1984. But after series of discussions, the government publicly criticized the IMF around mid-1985 suggesting a deadlock over possibility of assessing IMF loan (Banguna, 1987). And by the period Buhari left office, Nigeria owed \$18,034.1milllion (CBN, op cit).

However, unlike the above two regimes, Babangida, quickly accepted complying with the IMF prescriptions without considering the interest of the Nigerian masses. The simple logic is that the IMF wants to assert its hegemony over Nigeria at all cost, while Nigeria under Babangida's regime in the same ball game, wants to assert its supremacy over the Nigerian citizens, without considering their conditions. This is what made the various groups in Nigeria to vehemently oppose the SAP and Babangida's regime diametrically, with the resultant riots, demonstrations and conflicts in the midst of suffering because of the excruciating effects of SAP. Having forced Nigerians to accept the IMF, in a bid to keep the tentacles of Nigeria's dependency on Westerners and their international financial institutions going; the debt crisis plummets, since Babangida's regime was unable to service her debts which as at 1989 have risen to $\$ 29.28$ million and by 1993 when he left office, the country was indebted to over $\$ 32$ million (CBN, ibid). In fact, it has been argued that the IFIs (particularly, the IMF and World Bank) and the West should be blamed for causing the Nigeria's debt crisis. This is because,

At the close of the day a situation was created in the process of the international trade between Nigeria and the West was exploited by the IFIs and the West to create foreign debts and a debt crisis later in Nigeria. Also, the process was used to create stolen wealth for Nigerians, the IFIs and the West at the detriment of Nigeria (AFRODAD, op cit: 9).

\section{Conclusion}

In summary, therefore, Nigerian leaders, IFIs and the West have individually or jointly involved in the plot to the looting of a huge volume of Nigeria's external loans as well as domestic resources. This has made the nation's debt crisis critical, coupled with the failed polices of IMF through its SAP economic reforms. Really, when a cost comparative analysis is taken of the social/environmental damage, political unrest, conflicts, insecurity and sufferings inflicted on Nigerians by the policies of the IFIs, particularly IMF's SAP and sovereign governments of the West, the irresistible conclusion is that Nigeria has already repaid all her debts in calculable terms. In fact what Nigeria needs is not debt repayment but payment of reparations to her years of colonial and neo-colonial exploitation by the West and the industrialized creditor nations. This exploitation was made possible through the dependency relationship and the introduction of liberal economic ideology in Africa and Nigeria in particular.

\section{References}

African Forum and Network On Debt and Development. (2007). Nigeria: Foreign Debts Stolen Wealth, IFIs and The West, A Case Study: AFRODAD.

Amin, Samir. (1994). 'Fifty Years is Enough (Part1)' South African Political and Economic Monthly (SAPEM) Zimbabwe: SAPEM Trust. Vol. 8 No 2 Nov.

Azani, Razi. (2005). Profligacy, corruption and debt, Daily Times: Pakistan February, 102005.

Bangura, Yusuf. (1987). 'IMF/World Bank Conditionality and Nigeria's Structural Adjustment Programme' Uppsala : Nordiska Afrikainstitutet.

Baran, Paul. (1957). The Political Economy of Growth, Monthly Review Press: New York.

Biersteker, T. J eds. (1993). Dealing With Debt: International Financial Negotiations and Adjustment Bargaining, Westview Press: Oxford.

Burchill, Scott et al. (1996). Theories of International Relations, Macmillan Press limited: London.

Central Bank of Nigeria (CBN), Annual Report 1988.

Cheryl, P. (1974). The Debt Trap: The IMF and Third World, Penguin Books Ltd: Middlesex.

Dare, Sunday. (2001). A Continent in Crisis, Africa and Globalization, Dollars and Sense Magazine, July/August.

Frank, A.G. (1971). Crisis in The Third World, Heinemann: London.

Havnewk, K. J. (ed). (1987). The IMF and The World Bank In Africa, Scandinawan Institute of African Studies: Sweden.

Holsti, K. J. (1995). International Politics: A Framework for Analysis, Princeton International Inc: New Jersey. 
Hyden, Goran, Hastings W.O. Okoth-Ogendo \& Bamidele Olowu eds. (2000). African Perspective on Governance, Africa World Press: Trento, NJ.

Ikejiaku, Brian-Vincent. (2008). The relationship between poverty, peace and development in Africa, political corruption emphasized 1960-2007: case studies of Nigeria and South Africa, Unpublished PhD Thesis, School of Politics, International Relations and Philosophy, Keele University, UK.

Ikejiaku, Brian-Vincent. (2009). The Relationship between Poverty, Conflict and Development, Journal of Sustainable Development, Vol. 2, No. 1, in March 2009, 'in press'.

Irungu, Houghton. (1994). The Aid Industry in East Africa, SAPEM Vol. 8 No. 2 Nov.

Offiong, D. (1989). Imperialism and Dependency, Obstacles to African Development, Fourth Dimension Pub: Enugu, Nigeria.

Okafor, Collins. (2004). Neo-Democracy and Poverty Management in Africa, Mercury Bright Press: Awka, Nigeria.

Onimode, Bade eds. (1989). The IMF, the World Bank and the African Debt, The Economic Impact, Zed Books Publication Ltd: London.

Our Common Interest. (2005). The Report of the Commission for Africa: Commission for Africa.

Rodney, Walter. (1972). How Europe Underdeveloped Africa, Bogle L'Ouverture pub: London.

Rostow, Walt W. (1960). The Stages of Economic Growth, Cambridge University Press: Cambridge.

Sachs, Jeffrey. (2005). The End of Poverty: How we can make it happen in our life: Penguin.

Sandbrook, R. (1982). The Politics of Basic Needs, Heinemann: London.

Sharitayanam D et al. (2001). Aid and Reform in Africa, World Bank Pub: Washington DC.

Wanyande, P. (1997). State Driven Conflict in the Greater Horn of Africa, USAID.

World Bank. (2000). Our Dream: A World Free of Poverty, World Bank Pub: Washington D.C.

Wrong, M. (2005). When the Money goes West, New Statesman: March 14, 2005. 